\title{
PENGARUH SARANA PRASARANA AKADEMIK, KUALITAS MENGAJAR DOSEN, ATMOSFER AKADEMIK, DAN MOTIVASI BELAJAR TERHADAP PRESTASI BELAJAR MAHASISWA
}

\author{
Khairudin Arafah \\ Universitas Negeri Makassar \\ Email:arafah556@gmail.com
}

\begin{abstract}
This research aims to know the effect of acedemic infrastruktur for lecturer qualities in teaching, Academic infrastruktur for academic atmosphere, academic infrastruktur for student motivation in learning, lecturer quality in teaching for academic atmosphere, lecturer quality in teaching for student achievement in learning, and motivation in study for student achievement in learning. For achieving those aims, we observed 51 students which is choose by simple random. The results of this research showed that academic infrastruktur give positif impact for lecturer quality in teaching
\end{abstract}

Keywords: Academic Infrastruktur, Teaching Quality, Academic Atmosphere, Motivation In Learning, International Class.

\begin{abstract}
Abstrak
Penelitian ini bertujuan untuk mengtahui pengaruh sarana prasarana akademik terhadap kualitas mengajar dosen, sarana prasarana akademik terhadap atmosfer akademik, sarana prasarana akademik terhadap motivasi belajar mahasiswa, atmosfir akademik terhadap motivasi belajar mahasiswa, kualitas mengajar dosen terhadap atmosfer akademik, kualitas mengajar dosen terha-dap prestasi belajar mahasiswa, dan motivasi belajar terhadap prestasi belajar mahasiswa. Untuk mencapai tujuan tersebut, telah dilakukan survey kepada 51 orang mahasiswa yang diambil se-cara acak sederhana. Hasil penelitian menunjukkan bahwa sarana prasarana akademik berpengaruh langsung positif terhadap kualitas mengajar dosen
\end{abstract}

Kata Kunci : Sarana Prasarana Akademik, Kualitas Mengajar, Atmosfer Akademik, Motivasi Belajar, Kelas Internasional

\section{PENDAHULUAN}

Mutu pendidikan terus menjadi perbincangan yang menarik di berbagai Negara termasuk Indonesia. Hal ini menarik karena kualitas sumber daya manusia suatu bangsa selalu dikaitkan dengan mutu pendidikannya. Demikian juga kemajuan suatu bangsa dapat dilihat melalui perkembangan ilmu pengeta-huan dan teknologinya.

Di Indonesia, mutu pendidikan selain masih rendah dibandingkan dengan negaranegara tetangga, juga pada tataran konsep ma-sih terus menjadi polemik. Jika konsep mutu diukur melalui tingkat kelulusan siswa Seko-lah Menengah Atas (SMA) seperti pada masa lalu sewaktu ujian sekolah diterapkan, maka mutu pendidikan kita dikatakan tinggi karena tingkat kelulusan siswa sangat tinggi. Namun, jika konsep mutu dikaitkan dengan tingkat pe-nyerapan lulusan di dunia kerja pada masa yang sama, maka mutu pendidikan kita dika-takan rendah. Kontradiksi ini masih terus berlanjut hingga penerapan ujian nasional, walaupun fenomenanya relative berbeda.

Kontroversi tentang mutu lulusan baik pada pendidikan menengah maupun pada pen-didikan tinggi serta ketertinggalan di bidang pendidikan ini mendorong pemerintah Indo-nesia untuk terus menyempurnakan sistem pendidikan baik pada jenjang pendidikan da-sar dan menengah, maupun pada jenjang pen- 
didikan tinggi. Keseriusan pemerintah untuk meningkatkan mutu pendidikan diwujudkan dalam bentuk undang-undang (UU) nomor 20 tahun 2003 tentang Sistem Pendidikan Nasio-nal.

Undang-undang nomor 20 tahun 2003 kemudian ditindaklanjuti pemerintah dengan menetapkan delapan standar nasional pendi-dikan yang diatur melalui Peraturan Pemerin-tah (PP) nomor 19 tahun 2005 tentang Standar Nasional Pendidikan (SNP). Kedelapan stan-dar tersebut adalah: standar isi, proses, kom-petensi lulusan, pendidik dan tenaga kependi-dikan, sarana dan prasarana, pengelolaan, pembiayaan, dan standar penilaian pendidik-an.

Pemerintah selain mengatur standar nasional pendidikan sebagai acuan dalam pe-nyelenggaraan pendidikan, juga member pelu-ang untuk menyelenggarakan pendidikan de-ngan mengacu standar nasional. Hal tersebut dicantum dalam UU No. 20 tahun 2003 pasal 50 ayat (3) yang menyatakan bahwa Pemerin-tah atau Pemerintah Daerah menyelenggara-kan sekurang-kurangnya satu satuan pendidik-an pada semua jenjang pendidikan, untuk dikembangkan menjadi satuan pendidikan yang bertaraf internasional.

Sekolah Bertaraf Internasional (SBI), yaitu sekolah/madrasah yang menggunakan dua bahasa (bilingual) terutama untuk mata pelajaran sains dan matematika. SBI merupa-kan sekolah/madrasah yang memenuhi selu-ruh SNP dan diperkaya dengan muatan-muat-an yang mengacu pada standar pendidikan dari sekurang-kurangnya satu Negara anggota organisasi kerjasama dalam bidang ekonomi dan pengembangan atau Organization For Economic Cooperation And Development (OECD) dan atau Negara maju lainnya yang mempunyai keunggulan tertentu dalam bidang pendidikan sehingga memiliki daya saing di tingkat internasional. Standar SBI dapat diru-muskan sebagai $\mathrm{SBI}=\mathrm{SNP}+\mathrm{X}$. SNP meru-pakan pelaksanaan delapan standar nasional pendidikan yang diamanatkan oleh PP 19 ta-hun 2005.
Sementara $\mathrm{X}$ merupakan penguat-an, pengayaan, pengembangan, perluasan dan pendalaman melalui adaptasi atau adopsi terhadap standar pendidikan baik dari dalam maupun luar negeri yang diyakini telah memiliki reputasi mutu yang diakui secara inter-nasional.

Namun demikian, kenyataan di lapangan menunjukkan bahwa tidak semua seko-lah/madrasah yang berstandar internasional dapat memenuhi persyaratan tersebut. Akibat-nya, SBI tidak sepenuhnya berjalan sesuai de-ngan harapan. Salah satu permasalahan yang diduga menjadi penyebabnya adalah belum adanya sinergi antara perguruan tinggi peng-hasil guru dengan penyelenggaraan SBI. Ke-bijakan pemerintah untuk menyelenggarakan SBI nampaknya tidak didahului oleh penyelenggaraan program kelas internasional di per-guruan tinggi.

Untuk mengatasi kesenjangan ini, pe-merintah kemudian member kesempatan ke-pada para guru SBI di bidang studi sains dan Matematika untuk memperdalam Bahasa Ing-gris baik dalam bentuk kursus maupun studi lanjut ke program magister. Kebijakan ini tampaknya dapat menyelesaikan sebagian per-masalahan dalam persoalan bahasa, akan te-tapi permasalahanmetodologi pengajaran be-lum dapat teratasi secara sempurna.

Dalam rangka mengatasi persoalan pe-nyediaan pendidik (khususnya guru) SBI ini, pemerintah kemudian member peluang kepa-da perguruan tinggi untuk menyelenggarakan program pengadaan guru sains dan Matema-tika dalam bentuk program kelas internasional (Internasitional Class Program, ICP). Kom-petensi pendidik SBI harus memenuhi standar kualifikasi akademik dan kompetensi guru, di-perkaya dengan standar kompetensi pendidik yang berstandar internasional.

Salah satu perguruan tinggi yang men-dapat mandate dari pemerintah melalui Direk-torat Jenderal Pendidikan tinggi untuk menye-lenggarakan ICP yaitu Universitas Negeri Ma-kssar (UNM). Dalam upaya 
menghasilkan lu-lusan FMIPA UNM yang berkualitas, banyak faktor yang berpengaruh antara lain, dosen yang berkualitas, iklim akademik yang kon-dusif, dukungan sarana dan prasarana yang memadai, proses pembelajaran yang baik, sis-tem penilaian yang sesuai, dan banyak hal lainnya.

Proses pembelajaran yang produktif sangat dipengaruhi oleh kemampuan dosen dalam mengelola pembelajaran. Pengelolaan pembelajaran yang dimaksud di sini adalah pengelolaan perkuliahan baik dalam bentuk tahap muka maupun non tatap muka yang ber-tujuan untuk menciptakan proses pembelajar-an yang nyaman dan memungkin-kan maha-siswa dapat belajar secara maksimal dan ber-daya guna. Dalam konteks ini, peran dosen menjadi sangat penting.

Menurut Rosyada secara umum dosen harus memenuhi dua kategori yaitu memiliki capability dan loyality, yakni dosen harus me-miliki kemampuan dalam bidang ilmu yang diajarkannya, memiliki kemampuan teoretik tentang mengajar yang baik, dari mulai peren-canaan, implementasi sampai evaluasi, dan memiliki loyalitas keguruan, yakni loyal ter-hadap tugas-tugas keguruan yang tidak sema-ta-mata di dalam kelas, tetapi sebelum dan sesudah di dalam kelas. Sementara itu Hunt menyatakan bahwa dosen yang baik harus memenuhi tujuh kriteria, yaitu: sifat, pengeta-huan, apa yang disampaikan, bagaimana mengajar, harapan, reaksi dosen terhadap ma-hasiswa, dan managemen.

Berdasarkan pendapat Rosyada dan Hunt diatas, dapat disimpulkan bahwa seorang dosen yang berkualitas harus memiliki kemampuan dalam bidang ilmu yang diajarkan, memiliki ilmu tentang bagaimana menyampaikan ilmu tersebut, mempunyai ilmu untuk membelajarkan dan memiliki pula ilmu bagaimana membuat perencanaan untuk sebu-ah aktivitas pembelajaran yang menarik dan menantang.

Dengan demikian, seorang dosen yang berkualitas dalam mengajar harus memiliki berbagai kriteria yang diduga diperlukan un-tuk pembelajaran antara lain: 169 cara dosen me-nyampaikan materi kuliah, cara dosen berko-munikasi, kemampuan dosen dalam meman-cing mahasiswa untuk betanya, cara dosen memberi umpan balik, cara dosen menilai hasil karya mahasiswa, dan penggunaan me-dia pembelajaran yang tepat dalam proses pembelajaran.

Sehibingan dengan uraian di atas, me-nempatkan dosen sebagai salah satu objek ka-jian merupakan salah satu hal yang sangat menarik terutama jika dikaitkan dengan kua-litas atau mutu lulusan. Bertumpu pada kenya-taan inilah maka masalah yang berhubungan dengan kualitas mengajar dosen layak untuk diteliti.

Selanjutnya salah satu faktor yang di-duga mempengaruhi motivasi belajar dan prestasi belajar mahasiswa adalah iklim akademik yang kondusif. Iklim akademik yang kondusif adalah suasana yang mendorong in-teraksi positif antara dosen dengan dosen, do-sen dengan mahasiswa, dan mahasiswa de-ngan mahasiswa dalam lingkup pendidikan pengajaran, penelitian, dan pengabdian pada masyarakat.

Dalam ungkapan yang lain dikatakan bahwa iklim akademik menyangkut kondisi yang seluruh sumberdaya utamanya dosen da-pat mengembangkan kondisi perbaikan akade-mik yang meliputi kegiatan seminar, diskusi, pemberdayaan konsentrasi sampai kepada pengasuhan dosen muda oleh dosen senior.

Hubungan social yang baik antara do-sen dengan mahasiswa merupakan salah satu modal utama terselenggaranya komunikasi yang kondusif dan dapat berkontribusi positif dalam peningkatan motivasi belajar mahasis-wa. Demikian juga hubungan yang baik antara sesame mahasiswa dapat meningkatkan ker-ja sama mereka yang pada akhirnya juga dapat berkontribusi terhadap peningkatan motivasi belajar mahasiswa.

Dalam berbagai penelitian tentang hu-bungan antara motivasi belajar dengan pres-tasi belajar diperoleh kesamaam bahwa iklim akademik telah terbukti memberikan penga-ruh yang kuat terhadap pencapaian hasil-hasil akademik mahasiswa. Hasil 
tinjauan ulang yang dilakukan kuat terhadap pencapaian ha-sil-hasil akademik mahasiswa. Hasil tinjauan ulang yang dilakukan Anderson terhadap 40 studi tentang iklim sekolah sepanjang tahun 1964 sampai dengan 1980 menyatakan bah-wa hamper lebih dari setengahnya menunjukkan bahwa komitmen guru yang tinggi, norma hubungan kelompok sebaya yang positif, kerja sama tim, ekspektasi yang tinggi dari guru dan administrator, konsistensi dan pergu-ruan tentang hukuman dan ganjaran, konsen-sus tentang kurikulum dan pembelajaran, serta kejelasan tujuan dan sasaran telah mem-be-rikan sumbangan yang berharga terhadap pen-capaian hasil akademik siswa.

Hubungan sosial antara siswa dengan guru yang mutualistik merupakan unsure pen-ting dalam kehidupan sekolah. Guru yang me-miliki interest, peduli, adil, demokratis, dan respek terhadap siswa nya ternyata telah mampu mengurangi tingkat drop out siswa, tinggal kelas dan berperilaku menyimpang di kalangan siswa. Lebih lanjut dilaporkan oleh Wentzel bahwa iklim sekolah memiliki hu-bungan yang positif dengan motivasi belajar siswa.

Studi yang dilakukan Stockard, dan Mayberry menyimpulkan bahwa iklim sekolah, yang mencakup: ekspektasi prestasi siswa yang tinggi, lingkungan sekolah yang teratur, moral yang tinggi, perlakuan terhadap siswa yang positif, penyertaan aktivitas siswa yang tinggi dan hubungan social yang positif ter-nyata memiliki korelasi yang kuat dengan hasil-hasil akademik siswa.

Selanjutnya keberhasilan penyelenggaraan pendidikan baik pada jenjang pendidikan dasar dan menengah maupun jenjang pendidikan tinggi dipengaruhi oleh seberapa besar dukungan sarana dan prasarana akademik. Dalam lampiran Peraturan Menteri Pen-didikan Nasional (Permendiknas) Nomor 24 Tahun 2007 tentang Standar Sarana dan Pra-sarana Pendidikan Dasar dan Menengah dika-takan bahwa sarana adalah standar nasional pendidikan yang berkaitan dengan criteria mi-nimal tentang ruang belajar, tempat olahraga, tempat ibadah, perpustakaan, laboratorium, bengkel kerja, tempat bermain, tempat ber-ekreasi, serta sumber belajar lain, yang diper-lukan untuk menunjang proses pembelajaran, termasuk penggunaan teknologi informasi dan komunikasi.

Lebih lanjut dalam pasal 42 ayat (1) dikatakan bahwa setiap satuan pendidikan wa-jib memiliki sarana yang meliputi perabot, peralatan pendidika, media pendidikan, buku dan sumber belajar lainnya, bahan habis pa-kai, serta perlengkapan lain yang diperlukan untuk menunjang proses pembelajaran yang teratur dan berkelanjutan. Pasal 42 ayat (2); setiap satuan pendidikan wajib memiliki prasarana yang meliputi lahan, ruang kelas, ruang pimpinan satuan pendidikan, ruang guru, ru-ang tata usaha, ruang perpustakaan, ruang la-boratorium, ruang bengkel kerja, ruang unit produksi, ruang kantin, instalansi daya dan ja-sa, tempat berolahraga, tempat beribadah, tempat bermain, tempat berkreasi, dan ruang/ tempat lain yang diperlukan untuk menunjang proses pembelajaran yang teratur dan berkelanjutan.

Kriteria minimum dalam standar sarana dan prasarana dijabarkan sebagai ketentuan minimum tentang jenis, rasio, dimensi, kriteria, prosedur, dan legalitas yang berkaitan dengan perencanaan, pelaksanaan pengadaan, dan pemeliharaan, serta pengawasan sarana dan prasarana pendidikan yang diperlukan un-tuk menunjang pembelajaran.

Dalam penjabarannya kemudian dika-takan bahwa sarana akademik mencakup pera-botan dan peralatan yang diperlukan sebagai kelengkapan setiap gedung/ruangan dalam menjalankan fungsinya untuk meningkatkan mutu dan relevansihasil produk dan layanan-nya.

Berdasarkan jenisnya, sarana dibagi dalam dua kelompok yaitu: 1) Sarana pembe-lajaran, mencakup (a) sarana untuk melaksa-nakan proses pembelajaran sebagai 
keleng-kapan di ruang kelas, seperti papan tulis, OHP, LCD, microphone, alat peraga, bahan habis pakai dan lain-lain; (b) peralatan labo-ratorium, sesuai jenis laboratorium masing-masing program studi; 2) Sarana sumber bela-jar terdiri dari buku teks, jurnal, majalah, lem-bar informasi, internet, intranet, CD-ROM dan citra satelit. Sumber belajar ini ha-rus di-seleksi, dipilah, dan disesuaikan denga tujuan pembelajaran.

Semakin besar dukungan sarana dan prasarana akademik diduga semakin besar peluang mahasiswa dan dosen memaksimalkan interaksi belajar mengajar di kelas. Selain itu, dengan dukungan sarana dan prasarana yang lengkap maka akan member dorongan kepada mahasiswa untuk meningkat-kan mo-tivasi belajarnya.

Berdasarkan uraian diatas dan Kenya-taan dilapangan menunjukkan bahwa kualitas mengajar dosen baik dalam lingkungan ma-sing-masing jurusan maupun dalam lingkung-an fakultas masih sangat beragam. Kebera -gaman itu dapat dipengaruhi oleh pengalaman mengajar, kualifikasi akademik, usia dan bi-dang kekhususan, serta talenta mengajar ma-singmasing dosen. Dengan demikian kualitas mengajar dosen FMIPA terutama yang meng-ajar pada ICP perlu mendapat kajian dalam bentuk penelitian berdasarkan persepsi maha-siswa. Demikian juga iklim akademik dan du-kungan sarana prasarana akademik dalam lingkungan FMIPA UNM terkhusus pada ICP dalam kaitannya dengan motivasi belajar dan prestasi belajar mahasiswa perlu diteliti.

Untuk lebih memfokuskan batasan masalah, rumusan masalah penelitian ini ada-lah apakan sarana prasarana akademik, kua-litas mengajar dosen atmosfer akademik, dan motivasi belajar berpengaruh terhadap presta-si belajar mahasiswa?

\section{METODOLOGI PENELITIAN}

Sesuai Dengan latar belakang dan rumusan masalah yang ditemukan, penelitian ini dilakukan dengan tujuan untuk mengeta-hui: 1) Pengaruh kualitas mengajar dosen dan motivasi belajar mahasiswa terhadap prestasi belajar mahasiswa international class prog-ram (ICP) Jurusan Fisika Fakultas Matema-tika dan Ilmu Pengetahuan Alam (FMIPA) Universitas Negeri Makasar (UNM), 2) Pe-ngaruh kualitas mengajar dosen, atmosfer akademik, akses mahasiswa terhadap sarana dan prasarana akademik terhadap motivasi belajar mahasiswa ICP Jurusan FMIPA UNM, dan 3) Pengaruh kualitas mengajar dosen dan akses mahasiswa terhadap sarana dan prasara-na akademik terhadap atmosfir akademik ICP Jurusan Fisika FMIPA UNM Makasar.

Penelitian ini dilaksanakan pada mahasiswa ICP Jurusan Pendidikan Fisika FMIPA UNM, yang dimuali pada bulan April sampai dengan Agustus 2010. Jenis penelitian ini adalah expost-facto dengan menggunakan model penelitian survey dengan teknik anali-sis structural equation modeling (SEM). Mo-del structural dan pengukuran yang sesuai de-ngan kondisi penelitian.

Jumlah penelitian ini sebanyak 51 orang. Tentang jumlah sampel ini, Tenenhaus (2007: 33-37) menjelang bahwa SEM dapat digunakan dalam sampel kecil, bahkan dalam tulisannya dipaparkan penggunaan SEM un--tuk sampel yang berjumlah 24 dan 27. Seja-lan dengan Tenenhaus, Tilaar (2009:55) juga telah melakukan penelitian dengan menggu-nakan analisis SEM pada 51 sampel.

Ada lima macam data yang dikumpul dalam penelitian ini, yaitu 1) data prestasi be-lajar mahasiswa, 2) data motivasi belajar ma-hasiswa, 3) data kualitas mengajar dosen ber-dasarkan persepsi mahasiswa, 4) data atmos-fir akademik berdasarkan persepsi mahasis-wa, dan 5) data sarana dan prasarana akade-mik berdasarkan persepsi mahasiswa. Data prestasi belajar mahasiswa dikumpulkan me-lalui dokumentasi skor total masing-masing mata kuliah keahlian fisika yang terdiri atas: Fisika Dasar I, Fisika Dasar II, Elektronika Dasar, Fisika Matematika I, Fisika Matemati-ka II, Gelombang dan, Termodinamika. 
Selanjutnya data motivasi belajar ma-hasiswa diambil melalui pengukuran terhadap motivasi belajar mahasiswa malalui kuesio-ner. Data tentang atmosfir akademik, kualitas mengajar dosen, dan sarana prasarana akade-mik diambil melalui pengukuran persepsi ma-hasiswa kuesioner yang berskala lima.

Data yang terkmpul diolah melalui analisis deskriptif dan analissi SEM menggu-nakan software AMOS 16.0. dalam hal ini, SEM mengungkap analisis faktor dan analisis jalur.

\section{HASIL DAN PEMBAHASAN}

Analisis deskriptif yang digunakan da-lam penelitian ini adalah boxplot dan whis-kerplot yang hasilnya ditunjukan dalam gam-bar 2. Boxplot tersebut memperlihatkan bah-wa data variable sarana prasarana akademik $\left(\mathrm{X}_{1}\right)$ median $=81$, modus $=74$, interquartil range $=16.00$, skor minimum responden $=51$, skor maksimum responden $=111$, dan skewness $=0.025$. Dalam hal ini terdapat satu data outlier. Whisker bagian atas lebih pan-jang dari whiskerbagian bawah, yang menunjukan bahwa distribusi data sarana dan prasa-rana akademik ICP Jurusan Fisika FMIPA UNM sebagian besar berkumpul pada data yang lebih besar.

Selanjutnya boxplot data kualitas mengajar dosen memiliki median $=108$, modus $=95$, interquartill range $=18.00$, skor minimum responden $=85$, skor maksimum responden $=137$, dan skewness $=0.22$. Whisker bagian bawah lebih panjang dari whiskes bagian atas, yang menunjukkan bahwa distribusi data kualitas mengajar dosen cen-derung menjulur kearah kiri atau negatively skewness. Hal ini berarti bahwa data kualitas mengajar dosen ICP Jurusan Fisika FMIPA UNM se-bagian besar berkumpul pada data yang lebih kecil.

Boxplot data atmosfir akademik ICP Jurusan FISIKA FMIPA UNM dengan median $=75$, Modus $=63$, interquartill range $=$ 20.00 , skor minimum responden $=55$, skor maksimum responden $=95$, dan skewness $=$
0.047. Whisker bagian bawah lebih panjang dari whiskes bagian atas, yang menunjukkan bahwa disribusi data kualitsa mengajar dosen cenderung menjulur kearah kiri atau nega-tively skewness. Hal ini berarti bahwa data motivasi belajar mahasiswa ICP Jurusan Fi-sika FMIPA UNM sebagian besar berkumpul pada data yang lebih kecil.

Boxplot data atmosfir akademik ICP Jurusan FISIKA FMIPA UNM dengan median $=68.42$, Modus $=69.89$, interquartill range $=6.650$, skor minimum responden $=$ 59.14 , skor maksimum responden $=77$, dan skewness $=0.005$. Whisker bagian bawah lebih panjang dari whiskes bagian atas, yang menunjukkan bahwa disribusi data kualitsa mengajar dosen cenderung menjulur kearah kiri atau negatively skewness. Hal ini berarti bahwa data prestasi belajar mahasiswa ICP Jurusan Fisika FMIPA UNM sebagian besar berkumpul pada data yang lebih kecil.

Dengan demikian dapat disimpulkan bahwa variable prestasi belajar mahasiswa ( $\left.\mathrm{Y}_{4}\right)$ memiliki variasi data yang paling homo-gen disbanding dengan data empat variable la-innya yaitu: Sarana prasarana akademik $\left(\mathrm{X}_{1}\right)$, motivasi belajar mahasiswa $\left(\mathrm{Y}_{3}\right)$, kua-litas mengajar dosen $\left(\mathrm{Y}_{1}\right)$ dan variable atmos-fer akademik $\left(\mathrm{Y}_{2}\right)$.

\section{A. Pengujian Persyaratan Analisis}

Data yang terkumpul kemudian dilakukan uji reliabilitas menggunakan metode cronbach alpha dibantu dengan SPSS versi 14.0. hasil perhitung menunjukkan bahwa koe-fisien alpha msing-masing variable laten lebih besar dari 0.6 yang berarti masing-masing faktor dalam penelitian ini reliable.

\section{B. Analisis Faktor}

Analisis Faktor Konfirmatori Sarana Prasarana Akademik

Hasil analisis awal konstruk sarana prasarana akademik menunjukkan bahwa dari 28 butir yang dikonfirmasi melalui CFA, di-peroleh chi-square $=0.06 ; \mathrm{CMIN} / \mathrm{df}$ (rela-tivechi-square $)=0.06<2.00 ; \mathrm{p}$-value $=0.802>0.005 ;$ RMSEA $=0.00<0.08 ;$ TLI 
$=1.14>0.09 ;$ dan CFI $=1.00>0.09$. Hal ini menun-jukan bahwa model dipandang baik untuk digunakan dalam analisis lebih lanjut.

Berdasarkan hasil analisis data diketa-hui pula bahwa nilai bobot regresi menunjuk-kan bahwa critical ratio yang lebih besar dari dua kali standard error, yang berarti bahwa semua butir pada penelitian ini sahih terhadap setiap variabel penelitian secara konvergen. Hal ini berarti bahwa indicator sarana pembe-lajaran $\left(\mathrm{X}_{11}\right)$ dan sarana sumber belajar $\left(\mathrm{X}_{12}\right)$, Prasarana bangun $\left(\mathrm{X}_{13}\right)$, dan prasarana umum $\left(\mathrm{X}_{14}\right)$ sangat bermakna pada pembentukan variable laten sarana prasarana akademik. Dengan demikian, sarana prasarana akademik dapat direfleksikan oleh empat indikator ya-itu, sarana sumber belajar, sarana pembelajar-an, prasarana bangunan, dan prasarana umum.

\section{Analisis Faktor Konfirmatori Kualitas Me- ngajar Dosen}

Hasil analisis awal konstruk kualitas mengajar dosen menunjukkan bahwa dari 33 butir yang dikonfirmasi melalui CFA, dipero-leh chi-square $=9.38 ; \mathrm{CMIN} / \mathrm{df}$ $($ relativechi-square $)=1.26<2.00 ; \mathrm{p}$-value $=$ $0.802>0.005$; RMSEA $=0.06<0.08$; TLI $=0.97>0.90 ;$ dan CFI $=0.098>0.09$. Hal ini menun-jukkan bahwa model yang dibangun untuk menggambarkan kualitas mengajar dosen di-pandang baik untukdigunak dalam analisis le-bih lanjut. Dengan demikian, kualitas meng-ajar dosen dapat direfleksikan oleh enam indi-kator yaitu: tingkat kepandaian dosen menjelaskan materi kuliah, tingkat kepandaian dosen memeberikan penguatan, tingkat kepandaian dosen menilai hasil belajar mahasiswa, dan tingkat kepandaian dosen menggunakan media pembelajaran berbasis teknologi infor-masi.

\section{Analisis Faktor Konfirmatori Atmosfir aka- demik}

Hasil analisis awal konstruk atmosfir mengajar dosen menunjukkan bahwa dari 23 butir yang dikonfirmasi melalui CFA, dipero-leh chi-square $=2.52 ; \mathrm{CMIN} / \mathrm{df}$ 173
$($ relativechi-square $)=1.26<2.00 ; \mathrm{p}$-value $=$ $0.28>0.05 ;$ RMSEA $=0.07<0.08 ;$ TLI $=$ $0.98>0.90$; dan CFI $=0.099>0.090$. hal ini menunjukkan bahwa model dipandang baik untuk diguna-kan dalam analisis lebih lanjut. Dengan demi-kian, atmosfir dapat direfleksikan oleh empat indikator yaitu: etika akademik, budaya aka-demik, interaksi akademik, dan keterlibatan sivitas akademik dalam kegiatan akademik.

\section{Analisis Faktor Konfirmatori Motivasi Bela- jar Mahasiswa}

Hasil analisis awal konstruk motivasi belajar mahasiswa menunjukkan bahwa dari 30 butir yang dikonfirmasi melalui CFA, diperoleh chi-square $=9.15 ; \mathrm{CMIN} / \mathrm{df}$ (relativechi-square $)=1.14<2.00 ; \mathrm{p}$-value $=0.33$ $>0.05 ;$ RMSEA $=0.05<0.08 ; \mathrm{TLI}=0.99>$ 0.90 ; dan CFI $=0.099>0.090$. hal ini menunjukkan bahwa model dipandang baik untuk digunakan dalam analisi lebih lanjut. Dengan demikian, motivasi belajar mahasiswa dapat direfleksikan oleh enam indicator yaitu: kebutuhan, berusaha unggul/ulet dalam meng-hadapi masalah, harapan sukses, menyele-saikan tugas-tugas dengan baik, berusaha se-mangat dalam belajar, dan inisiatif.

\section{Pengujian Hipotesis dan Pembahasan Uji Kecocokan Keseluruhan Model}

Dari hasil analisis awal model, menun-jukkan bahwa indeks overall model fit yang diperolah untuk tiap tahap awal adalah chi-cquare $=240.965 ; \mathrm{CMIN} / \mathrm{df}$ (relative chis-quare $)=1.324<2.00 ; p$-value $=0.002<0.05 ;$ RMSEA $=0.08 \leq 0.08$; TLI $=0.879<0.09 ;$ dan $\mathrm{CFI}=0.895<0.90$. Hal tersebut menunjukkan bahwa indeks model fit kurang baik secara marginal: chi-square, p-value, CFI, dan TLI kurang memberikan dukungan terhadap kebaikan model.

Selanjutnya, hasil estimasi parameter melalui regression weight atau loading faktor melalui metode maksimum likehood disajikan dalam lampiran 6.5. hasil analisis untuk mo-del ini belum dapat disajikan patokan dalam estimasi parameter karena model belum me-nunukan indeks fit yang 
acceptable. Akibat-nya, masih diperlukan langkah untuk mening-katkan overall index fit model tersebut. Pende-katan yang digunakan dalam me-ningkatkan indeks model fit tersebut adalah pendekatan model building-trimming terhadap parameter melalui pertimbangan modification indices yang disediakan oleh AMOS 16.0.

Fasilitas modification indices disediakan AMOS 16.0 dapat dijelaskan secara teori se-bagai berikut. Model yang dibangun sesung-guhnya dapat dipandang sebagai sebuah sis-tem yang di dalamnya dapat terjadi interaksi antarindikator yang membangun variabel. In-teraksi ini ada yang meningkatkan fit model dan ada yang justri dapat menurunkannya. Untuk meningkatkan dukungan terhadap fit model diperlukan pengganda Lagrange da-lam matriks varians-kovarians yang dalam soft-ware AMOS 16.0 disebut sebagai modi-fica-tion indices.

Software computer memberikan informasi bahwa suku-suku antar error memerlukan pengganda Lagrange sgsr model menjadi fit dengan cara menghubungkan pengganda Lagrange paling besar sumbangannya dalam peningkatan fit model yang tersedia dalam AMOS 16.0. Dalam hal ini error pada indi-kator lain yang tidak diteliti harus diverifikasi dengan teori yang telah dibangun. Dengan mempertimbangkan itu semua, maka hasil analisis tahap final yang diperoleh melalui modification indices.

Overall model fit untuk model ini adalah chi-square $=190.718 ; \mathrm{CMIN} / \mathrm{df}$ (relative chi-square $)=1.115<2.00 ;$-value $=0.144$ $>0.05:$ RMSEA $=0.048<0.08 ;$ TLI $=0.957$ $>0.90$; dan $\mathrm{CFI}=0.965>0.90$. hasil ini menunjukkan bahwa indeks model fit telah baik secara marginal dan memberikan dukungan terhadap kebaikan model.

Selanjutnya hasil estimasi parameter memberikan informasi bahwa terdapat 4 (em-pat) parameter pengaruh yang tidak signifikan pada taraf $\alpha=0.05$ atau dapat dikatakan data tidak mendukung hipotesis yang dibangun, yaitu sarana prasarana akademik terhadap at-mosfir akademik; sarana prasarana akademik, kualitas mengajar dosen terhadap motivasi be-lajar mahasiswa, dan atmosfir akademik terhadap motivasi belajar maha-siswa.

Hasil perhitungan intercepts serta squa-red multiple correlation $\mathrm{R}^{2}$ maka persamaan struktural model akhir adalah:

$$
\begin{aligned}
\mathrm{Y}_{1}=11.78+1.796 \mathrm{X}_{1} \\
\mathrm{R}^{2}=62.7 \% \\
\mathrm{Y}_{2}=0.603+0.767 \mathrm{X}_{1}+1.277 \mathrm{Y}_{1} \\
\mathrm{R}^{2}=77.0 \% \\
\mathrm{Y}_{3}=-2.339+0.183 \mathrm{X}_{1}+0.416 \mathrm{Y}_{1}+ \\
0.200 \mathrm{Y}_{2} \\
\mathrm{R}^{2}=77.7 \% \\
\mathrm{Y}_{4}=53.072+0.872 \mathrm{Y}_{1}+ \\
0.928 \overline{\mathrm{R}^{2}}=71.6 \%
\end{aligned}
$$

$\mathrm{X}_{1}$ adalah sarana prasarana akademik yang dipersepsikan. $Y_{1}, Y_{2}, Y_{3}$ dan $Y_{4}$ berturut-turut adalah kualitas mengajar dosen yang dipersepsikan, atmosfir akademik yang diper-sepsikan, motivasi belajar mahasiswa dan prestasi belajar mahasiswa

\section{Analisis Mediasi Model}

Analisis mediasi terkait dengan penga-ruh langsung, tak langsung dan pengaruh to-tal. Model-model mediasi mengizinkan terja-dinya asosiasi yang tersusun ke dalam kom-ponen-komponen yang mengungkap mekanis-me kausal yang mungkin. Menurut Shrout \& Bolger yang dipertegas oleh Ihsan (2009 : 208) dikatakan bahwa model-model ini ber-manfaat untuk pengembangan teori dan juga untuk mengidentifikasi titik-titik intervensi yang mungkin dalam bidang kerja aplikasi.

\section{E. Hasil Pengujian Hipotesis}

Pengaruh Sarana Prasarana Akademik terhadap Kualitas Mengajar Dosen

Untuk membuktikan bahwa sarana prasarana ajademik $\left(\mathrm{X}_{1}\right)$ berpengaruh langsung positif terhadap kualitas mengajar dosen $\left(\mathrm{Y}_{1}\right)$, dilakukan pengujian hipotesis. Adapun hipotesis statistic yang akan diuji adalah se-perti berikut. 


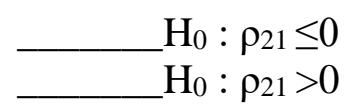

Hasil perhutungan menunjukkan esti-masi koefisien jalur $\rho_{21}=0.792$ dengan cri-tical ratio atau $t_{\text {hit }}=4.072$ lebih besar dari tab pada taraf signifikansi 0.05 sebesar 1.96. Hal ini berarti bahwa data tidak mendukung hipo-tesis $\mathrm{H}_{0}$ atau dinyatakan ditolak yang menun-jukan bahwa saran prasarana akademik memi-liki pengaruh positif terhadap kualitas meng-ajar dosen.

\section{Pengaruh Sarana Prasarana Akademik terhadap Atmosfir Akademik \\ Untuk membuktikan bahwa sarana} prasarana akademik $\left(\mathrm{X}_{1}\right)$ berpengaruh positif terhadap atmosfer akademik $\left(\mathrm{Y}_{2}\right)$ maka dila-kukan pengujian hipotesis. Adapun hipotesis statistik yang akan diuji adalah seperti berikut

$$
\begin{aligned}
& \mathrm{H}_{0}: \rho_{31} \leq 0 \\
& \mathrm{H}_{0}: \rho_{31}>0
\end{aligned}
$$

Dari hasil perhitungan diperoleh esti-masi koefisien jalur $\rho_{31}=0.190$ dengan cri-tical ratio atau $t_{\text {hit }}=0.693$ lebih kecil dari $\mathrm{t}_{\text {tab }}$ pada taraf signifikansi 0.05 sebesar 1.96. hal ini berarti bahwa data mendukung diterima-nya hipotesis $\mathrm{H}_{0}$ yang menunjukkan bahwa sa-rana prasarana akademik tidak berpengaruh langsung terhadap atmosfir akademik.

Walaupun berbeda dengan kajian teori yang telah dikembangkan pada bagian terda-hulu namun masih terdapat beebrapa hal yang menarik untuk dikaji lebih lanjut antara lain, perlu adanya peneliususran kebijakan pimpin-an mengenai sistem regulasi pemanfaatan sa-rana prasarana akademik yang dimiliki ICP Jurusan Fisika FMIPA UNM. Bisa jadi sarana prasarana akademik tidak dimanfaatkan seca-ra maksimal oleh sivitas akademik karena regulasinya tidak jelas sehingga dukungan sarana prasarana akademik menjadi tidak maksi-mal dalam upaya menciptakan atmosfir aka-demik yang kondusif.

Hal menarik lainnya yang dapat dikaji dari hasil pengujian hipotesis ini adalah per-sentase pengaruh tidak langsung sarana prasa-rana akademik terhadap atmosfir akademik melalui kualitas mengajar dosen yang cukup besar yaitu $56.9 \%$. Ini berarti bahwa walupun secara sendiri sarana prasarana akademik ti-dak berpengaruh langsung terhadap pembentukan atmosfir akademik yang kondusif namun secara bersama-sama dengan variabel kualitas mengajar dosen ternyata dapat memiliki pengaruh yang cukup tinggi. Hasil ini konsisten dengan teori yang dikemukakan oleh Ditjen Dikti yang menyatakan bahwa at-mosfir akademik secara bersama-sama diba-ngun oleh sarana prasarana akademik dengan variable lainnya seperti kualitas mengajar do-sen, dan proses akademik lainnya.

Dengan demikian, jika atmosfir akade-mik ICP Jurusan Fisika FMIPA UNM ingin ditingkatkan menjadi lebih kondusif maka va-riable yang patut dipertimbangkan untuk di-sempurnakan terlebih dahulu adalah variable sarana prasarana akademik dan sekaligus me-ningkatkan kualitas mengajar dosen ICP Jurusan Fisika FMIPA UNM Makassar.

Pengaruh Sarana Prasarana Akademik terhadap Motivasi Belajar Mahasiswa

Untuk membuktikan bahwa sarana prasarana akademik $\left(\mathrm{X}_{1}\right)$ berpengaruh langsung positif terhadap motivasi belajar mahasiswa $\left(\mathrm{Y}_{3}\right)$, maka dilakukan pengujian hipotesis. Adapun Hipotesis statistic yang akan di-uji adalah seperti berikut.

$$
\begin{aligned}
& \mathrm{H}_{0}: \rho_{41} \leq 0 \\
& \mathrm{H}_{0}: \rho_{41}>0
\end{aligned}
$$

Dari hasil perhitungan, diperoleh esti-masi koefisien jalur $\rho_{41}=0.088$ dengan cri-tical ratio atau $t_{\text {hit }}=0.390$ lebih besar dari $\mathrm{t}_{\text {tab }}$ pada taraf signifikansi 0.05 sebesar 1.96. hal ini berarti bahwa data mendukung diterima-nya hipotesis $\mathrm{H}_{0}$ yang 
menunjukkan bahwa sarana prasarana akademik tidak berpengaruh langsung terhadap motivasi belajar mahasis-wa.

Besarnya pengaruh tidak langsung sa-rana prasarana akademik terhadap motivasi belajar mahasiswa melalui variable kualitas mengajar dosen sebesar $35.7 \%$, melalui at-mosfir akademik sebesar $7.3 \%$, dan pengaruh tidak langsung sarana prasarana akademik terhadap motivasi belajar mahasiswa melalui kualitas mengajar dosen dan atmosfir aka-demik sebesar $22.1 \%$. besarnya pengaruh ti-dak langsung sarana prasarana akademik ter-hadap motivasi belajar mahasiswa yaitu $65.1 \%$.

Hasil penelitian ini dapat dijelaskan bahwa secara ekstrinsik motivasi belajar mahasiswa tidak dipengaruhi secara langsung oleh sarana prasarana akademik, melainkan dipengaruhi secara berssama-sama oleh kualitas mengajar dosen dengan atmosfir akademik, dan atmosfir akademik melalui peningkatan kualitas m,engajar dosen. Hal ini berarti bahwa jika motivasi belajar mahasiswa ingin ditinghkatkan maka selain harus me-lengkapi sarana prasarana akademik di ICP Jurusan Fisika FMIPA UNM, juga patut di-pertimbangkan untuk meningkatkan kualitas mengajar dosen dan membuat atmosfir akade-mik menjadi lebih kondusif.

\section{Pengaruh Atmosfir Akademik terhadap Moti-vasi Belajar Mahasiswa}

Untuk membuktikan bahwa atmosfir akademik $\left(\mathrm{Y}_{2}\right)$ berpengaruh langsung positif terhadap motivasi belajar mahasiswa $\left(\mathrm{Y}_{3}\right)$, maka dilakukan pengujian hipotesis. Adapun Hipotesis statistic yang akan diuji adalah seperti berikut.

$$
\begin{aligned}
& \mathrm{H}_{0}: \rho_{43} \leq 0 \\
& \mathrm{H}_{0}: \rho_{43}>0
\end{aligned}
$$

Dari hasil perhitungan, diperoleh esti-masi koefisien jalur $\rho_{43}=0.386$ dengan cri-tical ratio atau $t_{\text {hit }}=2.595$ lebih besar dari $\mathrm{t}_{\text {tab }}$ pada taraf signifikansi 0.05 sebesar 1.96. hal ini berarti bahwa data mendukung diterima-nya hipotesis $\mathrm{H}_{0} \quad$ yang menunjukkan bahwa atmosfir akademik tidak berpengaruh lang-sung terhadap motivasi belajar mahasiswa.

Hasil penelitian ini agak berbeda de-ngan teori yang telah dibangun pada $\mathrm{Bab}$ II yang menyatakan bahwa atmosfir akademik yang kondusif memebuat mahasiswa termo-tivasi belajar. Hal ini tersebut sejalan dengan pendapat Wentzel dalam Gallay (2004: 18) yang melaporkan bahwa iklim sekolah memi-liki hubungan yang positif dengan motivasi belajar siswa.

Perbedaan antara teori yang dibangun dengan hasil penelitian ini diduga diakibatkan oleh adanya variabel moderator yang tidak di-identifikasi oleh peneliti. Atmosfir akademik yang kondusif cenderung membangun rasa nyaman bagi mahasiswa untuk belajar di kam-pus. Namun demikian kampus atau di rumah. Bagi mahasiswa yang memiliki kecenderung-an belajar dirumah lebih besar dibandingkan di kampus, maka dapat berakibat kepada me-nurunnya motivasi belajar.

Hal ini berarti bahwa walaupun atmosfir akademik cukup kondusif untuk merangsang mahasiswa lebih giat belajar namun jika tidak didukung oleh kebiasaan belajar di kampus maka diduga mereka tidak dapat ter-motivasi belajarnya secara maksimal. Akibat-nya motivasi belajar mahasiswa ICP Jurusan Fisika FMIPA UNM tidak dipengaruhi secara langsung oleh atmosfir akademik.

Pengaruh Kualitas Mengajar Dosen terhadap Atmosfir Akademik

Untuk membuktikan bahwa kualitas mengajar dosen $\left(\mathrm{Y}_{1}\right)$ berpengaruh langsung positif terhadap atmosfir akademik $\left(\mathrm{Y}_{2}\right)$, dila-kukan pengujian hipotesis. Adapun Hipotesis statistik yang akan diuji adalah seperti berikut.

$$
\begin{aligned}
& H_{0}: \rho_{32} \leq 0 \\
& H_{0}: \rho_{32}>0
\end{aligned}
$$


Dari hasil perhitungan, diperoleh esti-masi koefisien jalur $\rho_{32}=0.719$ dengan cri-tical ratio atau $t_{\text {hit }}=2.595$ lebih besar dari $\mathrm{t}_{\text {tab }}$ pada taraf signifikansi 0.05 sebesar 1.96. hal ini berarti bahwa data tidak mendukung diteri-manya hipotesis $\mathrm{H}_{0}$ yang menunjukkan bahwa kualitas mengajar dosen memiliki pengaruh langsung positif terhadap atmosfir akademik.

Pengaruh Kualitas Mengajar Dosen terhadap Motivasi Belajar Mahasiswa

Untuk membuktikan bahwa kualitas mengajar dosen $\left(\mathrm{Y}_{1}\right)$ berpengaruh langsung positif terhadap atmosfir akademik $\left(\mathrm{Y}_{3}\right)$, maka dilakukan pengujian hipotesis. Adapun Hipo-tesis statistik yang akan diuji adalah seperti berikut.

$$
\begin{aligned}
& \mathrm{H}_{0}: \rho_{42} \leq 0 \\
& \mathrm{H}_{0}: \rho_{42}>0
\end{aligned}
$$

Dari hasil perhitungan, diperoleh esti-masi koefisien jalur $\rho_{42}=0.451$ dengan cri-tical ratio atau $t_{\text {hit }}=1.407$ lebih kecil dari $\mathrm{t}_{\text {tab }}$ pada taraf signifikansi 0.05 sebesar 1.96. Hal ini berarti bahwa data mendukung diterima-nya hipotesis $\mathrm{H}_{0}$ yang menunjukkan bahwa kualitas mengajar dosen tidak berpengaruh langsung terhadap motivasi belajar mahasis-wa.

Hasil penelitian ini agak berbeda de-ngan kajian teoretis yang menyatakan bahwa dosen yang berkualitas dalam mengajar dapat menambah rangsangan ekstrinsik motivasi belajar mahasiswa selain motivasi yang seca-ra instrinsik telah terbentuk.

Jika dilihat dari besarnya pengaruh langsung kualitas mengajar dosen terhadap motivasi belajar mahasiswa sebesar $4501 \%$ dan pengaruh tidak langsung melalui atmosfer akademik sebesar $27.8 \%$, maka hal ini me-nunjukkan bahwa walaupun secara sendiri ku-alitas mengajar dosen tidak berpengaruh lang-sung terhadap motivasi belajar mahasiswa.

Hasil penelitian ini member informasi yang cukup penting tentang dukungan kualitas mengajar dosen terhadap motivasi belajar ma-hasiswa melalui atmosfer akademik. Artinya, bahwa jika motivasi belajar maha-siswa ICP Jurusan Fisika FMIPA UNM ingin diperbesar, kualitas mengajar dosen harus ditingkatkan baik secara sendiri maupun secara bersamasama dengan penciptaan atmosfir akademik yang lebih kondusif di ICP Jurusan Fisika FMIPA UNM.

Pengaruh Kualitas Mengajar Dosen terhadap Prestasi Belajar Mahasiswa

Untuk membuktikan bahwa kualitas mengajar dosen $\left(\mathrm{Y}_{1}\right)$ berpengaruh langsung positif terhadap prestasi belajar $\left(\mathrm{Y}_{4}\right)$, maka dilakukan pengujian hipotesis. Adapun Hipo-tesis statistik yang akan diuji adalah seperti berikut.

$$
\begin{aligned}
& \mathrm{H}_{0}: \rho_{52} \leq 0 \\
& \mathrm{H}_{0}: \rho_{52}>0
\end{aligned}
$$

Dari hasil perhitungan, diperoleh esti-masi koefisien jalur $\rho_{52}=0.432$ dengan cri-tical ratio atau $t_{\text {hit }}=2.016$ lebih kecil dari $t_{\text {tab }}$ pada taraf signifikansi 0.05 sebesar 1.96. Hal ini berarti bahwa data tidak mendukung diteri-manya hipotesis $\mathrm{H}_{0}$ yang menunjukkan bahwa kualitas mengajar dosen tidak berpengaruh langsung terhadap motivasi belajar mahasis-wa.

Hasil tersebut diperkuat oleh besarnya pengaruh langsung kualitas mengajar dosen terhadap prestasi belajar mahasiswa yang se-besar $44.4 \%$. PEngaruh tidak langsung kuali-tas mengajar dosen terhadap prestasi belajar mahasiswa melalui motivasi belajar mahasis-wa sebesar $19.6 \%$, pengaruh tidak langsung kualitas mengajar dosen terhadap prestasi belajar mahasiswa melalui atmosfir akademik dan melalui motivasi belajarmahasis-wa sebe-sar 12.1 $\%$. Jadi besarnya pengaruh tidak langsung kualitas mengajar dosen terhadap prestasi belajar mahasiswa adalah $31.7 \%$ baik melalui motivasi belajar maha-siswa maupun melalui atmosfir akademik dan motivasi bela-jar mahasiswa.

Data hasil penelitian di atas memberi informasi bahwa dosen yang berkualitas 
mengajar dapat menciptakan atmosfer akademik yang kondusif, dan atmosfir akademik yang kondusif dapat meningkatkan motivasi belajar mahasiswa yang pada akhirnya dapat meningkatkan prestasi belajar mahasiswa.

\section{Pengaruh Motivasi Belajar terhadap} Prestasi Belajar Mahasiswa

Untuk membuktikan bahwa motivasi belajar mahasiswa $\left(\mathrm{Y}_{3}\right)$ berpengaruh langsung positif terhadap prestasi belajar mahasiswa $\left(\mathrm{Y}_{4}\right)$, maka dilakukan pengujian hipotesis. Adapun Hipotesis statistik yang akan diuji adalah seperti berikut.

$$
\begin{aligned}
& \mathrm{H}_{0}: \rho_{54} \leq 0 \\
& \mathrm{H}_{0}: \rho_{54}>0
\end{aligned}
$$

Dari hasil perhitungan, diperoleh esti-masi koefisien jalur $\rho_{54}=0.444$ dengan criti-cal ratio atau $t_{\text {hit }}=2.103$ lebih besar dari $t_{\text {tab }}$ pada taraf signifikansi 0.05 sebesar 1.96. Hal ini berarti bahwa data tidak cukup mendukung diterimanya hipotesis $\mathrm{H}_{0}$ yang menunjukkan bahwa kualitas mengajar dosen tidak berpe-ngaruh langsung terhadap motivasi belajar mahasiswa.

\section{PENUTUP}

\section{A. Simpulan}

Berdasarkan hasil analisis dan pemba-hasan yang telah dilakukan, dapat ditarik be-berapa kesimpulan. Sarana prasarana akade-mik berpengaruh langsung positif terhadap kualitas mengajar dosen. Hal ini berarti bahwa perbaikan sarana prasarana akademik ICP Jurusan Fisika FMIPA UNM akan mengaki-batkan peningkatan kualitas mengajar dosen.

Kualitas mengajar dosen berpengaruh positif terhadap atmosfir akademik. Hal ini berarti nahwa peningkatan kualitas mengajar dosen ICP Jurusan Fisika FMIPA UNM akan mengakibatkan terciptanya atmosfir akademik yang kondusif.

Kualitas mengajar dosen berpengaruh langsung positif terhadap prestasi belajar ma-hasiswa. Temuan ini berarti bahwa peningkat-an kualitas mengajar dosen ICP Jurusan Fi-sika FMIPA UNM akan mengakibatkan pe-ningkatan prestasi belajar mahasiswa.

Motivasi belajar mahasiswa secara langsung berpengaruh positif dan signifikan terhadap prestasi belajar mahasiswa. Hal ini berarti bahwa peningkatan motivasibelajar mahasiswa ICP Jurusan Fisika FMIPA UNM akan mengakibatkan peningkatan prestasi belajar mahasiswa ICP Jurusan Fisika FMIPA UNM.

\section{Saran}

Berttitik tolak dari kesimpulan pene-litian, dapat diajukan bebrapa saran yang di-harapkan dapat memeberi kontribusi dalam meningkatkan kualitas mengajar dosen, at-mosfir akademik yang lebih kondusif, dan meningkatkan motivasi belajar mahasiswa ICP Jurusan Fisika FMIPA UNM sebagai berikut:

Kepada pemangku kepentingan ICP Jurusan Fisika FMIPA UNM, disarankan un-tuk mempertimbangkan perbaikan sarana pra-sarana akademik menyangkut penambah-an: luas ruang organisasi kemahasiswaan (HMJ), jumlah hasil pengabdian masyarakat yang telah dilakukan dosen yang dpat diakses di perpustakaan, luas ruang perpustakaan, luas ruang penelitian, dan pengabdian masyarakat, jumlah hasil penelitian dosen yang dpat di-akses di perpustakaan, jumlah majalah nasi-onal pembelajaran fisika yang dapat diakses di perpustakaan, luas ruang teknologi infor-masi dan computer, jumlah jurnal nasional yang relevan dengan pembelajaran fisika yang dapa diakses di perpustakaan, jumlah bahan habis pakai di laboratorium yang mendukung pelaksanaan praktikum, luas ruang kuliah, luas ruang tata usaha, tingkat ketersediaan la-yanan internet di jurusan fisika, jumlah alat peraga yang digunakan dosen pada tiap kali mengajar, jumlah peralatan laboratorium elek-tronika yang dipergunakan dalam praktikum, dan 
ketersediaan jaringan telekomunikasi di kampus.

Kepada dosen ICP Jurusan Fisika FMIPA UNM sebaiknya: member pujian dalam bentuk komentar tertulis pada kertas/buku pekerjaan mahasiswa, menilai sekecil apapun aktivitas mahasiswa secara objektif, memeberi penguatan dengan cara membujuk, menepuk bahu, atau menepuk punggung mahasiswa, memeriksa tugas/hasil ujian dan mengembali-kannya kepada mahasiswa untuk melakukan keberatan sebelum mengeluarkan nilai akhir, mengakhiri perkuliahan tanpa menyimpulkan materi yang diajarkan, menggunakan model pembelajaran multi channel learning, menya-jikan materi kuliah tanpa memperhati-kan tingkat entry behavior mahasiswa, berjalan mendekati, berdiri didekat, atau duduk di de-kat kelompok mahasiswa pada saat diskusi berlangsung, menggunakan media internet dalam menyampaikan tugas-tugas perkuliah-an, dan dosen sebainya menyampai-kan ikhti-sar bahan kuliah pertemuan sebelumnya setiap mengawali perkuliahan.

Untuk menciptakan atmosfir akademik dalam lingkungan ICP Jurusan Fisika FMIPA UNM yang lebih kondusif, sebaiknya dosen bersama mahasiswa lebih sering menulis pa-per dan prestasi dalam berbagai seminar lokal dan nasional. Dalamberinteraksi dengan sivi-tas akademik, dosen menyatakan dirinya bu-kan sebagai seorang yang paling tahu tentang ilmu pengetahuan dalam bidang. Dosen lebih sering melakukan publikasi ilmiah pada jurnal baik local maupun nasional. Dosen pengampu mata kuliah lebih sering mendampingi asisten dalam pelaksanaan praktikum.

Dalammelaksanakan penelitian, dosen koordinator lebih sering berkolaborasi dengan dosen lainnya dan melibatkan sejumlah maha-siswa secara aktif. Dosen lebih sering mela-kukan penelitian ilmiah dan menuliskan la-porannya. Mahasiswa yang terlihat dan ter-bukti mencontek pada saat ujian diberi sanksi oleh dosen pengampuh mata kuliah. Dalam melaksanakan pengabdian masyarakat, dosen koordinator lebih sering berkolaborasi dengan dosen lainnya dan melibatkan sejumlah maha-siswa secara aktif.

Dosen lebih sering melakukan peneli-tian ilmiah dan menuliskan laporannya; pim-pinan jurusan lebih sering melaksanakan seminar staf/diskusi dengan melibatkan maha-siswa. Dosen memberi perlakuan yang sama terhadap mahasiswa yang ber-kepentingan da-lam kegiatan akademik tanpa didasarkan pada faktor gender, agama, suku, ras, fisik, dan status sosial agar nuansa kehidupan bermasyarakat yang majemuk di kampus ICP Jurus-an Fisika FMIPA dapat terwujud secara har-monis. Dosen lebih sering terlibat aktif dalam kegiatan yang diselenggaran oleh him-punan mahasiswa jurusan fisika; karyawan Jurusan Fisika lebih sering berperan aktif da-lam pem-berian layanan registrasi mata kuliah mahasis-wa; dan dosen lebih sering member layanan komunikasi kepada mahasiswa melalui email, milis maupun hand phone tanpa harus ke kampus untuk berkomunikasi dengan dosen.

Dalam upaya meningkatkan motivasi belajarnya, mahasiswa dianjurkan untuk: lebih sering mempelajari setiap materi kuliah keah-lian fisika lebih awal sebelum materi diajar-kan oleh dosen; mengerjakan soal-soal mata kuliah bukan hanya yang dianggap mudah saja; lebih giat belajar karena suasana akade-mik di kampus mendukung; mengisi waktu luang mereka dengan mempelajari materi ku-liah kaehlian fisika yang dapat menambah wa-wasan mereka ketimbang berkumpul dengan teman-teman; dan mahasiswa harus yakin bisa meyakinkan setiap ada tugas kuliah keahlian fisika walaupun sendirian.

Kiranya ada penelitian lanjutan terkait dengan penelitian ini yang menelusuri variabel-variabel moderator dari hubungan-hubungan yang telah dibangun dalam penelitian ini. 


\section{DAFTAR PUSTAKA}

Agung, I. G. N. (1998). Metode Penelitian Sosial 2 PEngertian dan Pemakaian Praktis. Jakarta: Gramedia Pustaka Utama.

(2006). Statistika Penerapan Model Re-rata-Sel Multivariat dan Model Ekonometri dengan SPSS. Jakarta: Yayasan Sad Satria Bhakti.

(2011). Cross Section and Experimental Data Analysis Using Eviewa. Singapore: Jhon Wiley \& Sons Pte. Ltd.

Akiba, M., Gerald, K. L. T., \& Jay, P. S. (2007). "Teacher Quality, Opportu-nity Gap, and National Achievement in 46 Countries". Educational Re-searcher, 36 (7), 369-387.

Alma, B. (2008). Guru Profesional: Menguasai Metode dan Trampil Meng-ajar. Bandung: Alfabeta.

Anom. (2006). Undang-undang Nomor 20 Ta-hun 2003 Tentang Sistem Pendidik-an Nasional. Jakarta: Badan Nasio-nal Standar Pendidikan.

. 2009). Pedoman Usulan Program Pengembangan Pendidikan Guru Matematika dan Sains Standar Internasional. Jakarta: Direktorat Pen-didikan Tinggi Derpartemen Pendi-dikan Nasional.

(2008). Buku I Naskah akademik Akreditasi Program Studi Sarjana. Jakarta: Badan Akreditasi Nasional Perguruan Tinggi.

. (2009). Draf Naskah Akademik Standar Sarana dan PRasarana
Pendidikan Tinggi Program Sarjana. Jakarta: Badan Standar Nasional Pendidikan.

(2008). Faktor-faktor yang Mempe-ngaruhi Motivasi Belajar, (Online),

(http://wongkeban.wordpress. com/2008/06/19/faktor-faktoryang-mempengaruhi-motivasibelajar, diakses 7 November 2008).

(2008). Motivasi Belajar dan Teori Disonan Kognitif Serta Implikasinya dalam Pendidikan, (Online), (http:/motivasibelajar.wordpress.com/20 08/05/16/02, diakses 7 Novem-ber 2008).

(2008). Pedoman Evaluasi Diri untuk Akreditasi Program Studi dan Institusi Perguruan Tinggi. Jakarta: Badan Akreditasi Nasional Perguru-an Tinggi.

. (2007). Pedoman Penjaminan Mutu Akademik Universitas Indonesia: Prasarana dan Sarana Akademik. Jakarta: Badan Penjaminan Mutu Akademik Universitas Indonesia.

(2007). Peraturan Menteri Pendidikan Nasional Republik Indonesia Nomor 24 Tahun 2007 Tentang Standar Sarana Prasarana Untuk Sekolah Dasar/Madrasah Ibtidaiyah (SD/MI), Sekolah Menengah Perta-ma/Madrasar Tsanawiyah (SMP/-MTs), dan Sekolah Menengah atas/ Madrasah Aliyah (SMA/MA). Jakar-ta: Badan Standar Nasional Pendi-dikan.

(2006). Peraturan Pemerintah Nomor 19 Tahun 2005 Tentang standar Nasional Pendidikan. 
Jurnal Parameter Volume 29 No. 2

DOI : doi.org/10.21009/parameter.292.05

P-ISSN : 0216-26IX

Jakarta: Badan Nasional Standar Pendidikan.

(2009). Sistem Penjaminan Mutu Akademis. Jakarta: Fakultas Ekono-mi Universitas Jambi

. (2008). Sistem Penjaminan Mutu Perguruan tinggi. Jakarta: Direktorat Jenderal Pendidikan Tinggi Depdik-nas.

. (2005). Tentang Guru dan Dosen. Jakarta: Departemen Pendidikan Na-sional.

Atkinson. J. W. (1981). An Introdaction to Motivation. New York: D Van Nos-trand Company Inc.

Bafadal, I. (2003). Manajemen Perlengkapan Sekolah. Jakarta: PT Bumi Aksara.

Belluck, D.A., Hull, R.N., Benjamin, S.L., Alcorn, J., and Linkov, I. Standard Risk Acceptability Criteria Applicable to Critical Infrastructure Based on Environmental Security Needs, (Online), (http://www. springerlink. com/content/4774661-676163208, diakses 21 Februari 2011.

Crawford, J. (1987). The Psychology Learning and Interaction. New Delhi: Prentice Hall

Davis, K., \& Newstorm, J. W. (1985). Human Behaviour at Work: Organizational Bahavior Seventh Edition. (A, Dgar-ma, Trans.). Jakarta: Erlangga.

Djaali., \& Mulyono, P. (2004). Pengukuran dalam Bidang Pendidikan. Jakarta: Program Pascasarjana Universitas Negeri Jakarta.
Djunaidi, M., Munawir, H., Togi Umi Utami. (2006). Evaluasi Kualitas Kinerja Proses Belajar Mengajar dengan Metode Focused Quality. Jurnal Il-miah Teknik Industri, Vol.5, No.1, Agustus.

Edward, S. (1993). Total Quality Management in Education. London: Kongan Page Limited.

Gagne, R. M. (1988). Prinsip-prinsip Belajar Untuk Pengajaran. Terjemahan oleh Abdilah Hanafi, \& Abdul Manan. Surabaya: Usaha Nasional.

Gallagher, H. A. (2002). The Relationship Between Measures Of Teacher Qua-lity and Student Achievement: The Case of Vaughn Elementary. Uni-versity of WisconsinMadison, De-partement of Educational Adminis-tration.

Gallay, L., Suet Ling Pong. (2009). School Climate and Students. Society for Prevention Research Annual Meeting, Quebec City, May 2004, (Online), http://www.pop.psu.edu/socresp/quebec1.pdf, diakses $22 \mathrm{Mei}$ 2009).

2009. School Climate and Student: Intervention Strategies, (Online), (http://akhmadsudrajat.wordpress. com/2008/03/29/iklim-sekolahkaitannnya-demham-hasilakademik -dan-non-akademiksiswa, diakses 25 Mei 2009).

Goetsch, D. L., \& Stanley B. D. (2000). Qua-lity Managemenet: Introduction to Total Quality Management for Pro-duction, Processing, and Services. New Jersey: Prentice Hall

Ghozali, I. (2008). Model Persamaan Struktural KONSEP dan APLIKASI de- 
ngan Program AMOS 16.0. Semarang: Bada Penerbit Universitas Di-ponegoro.

Gregory, R. J. (2000). Psychological Testing: History, Principles, and Application. USA: Allyn \& Bacon, Inc.

Hair, F.J., Anderson R.E., Tatham, R.L., \& Balck W.C. 1998. Multivariate Data Analysis $7^{\text {th }}$ Edition. New Jersey: Prentice Hall.

Hatton, N. (1996). "Chaning Initial Teacheer Education Limitations to Innovation in The United States, Australia, and United Kingdom". Australian Jour-nal of Teacher Education, Volume 21, No.2.

Hudoyo, H. (1991). Belajar Mengajar Matematika. Jakarta: Dikti.

Ihsan, H. (2009). "Analisis Pengaruh Kualitas dan Biaya Jasa yang Didepresia-sikan terhadap Kepuasan dan Loyal-itas Mahasiswa pada Pendidikan Tinggi di Sulawesi Selatan, Indone-sia". Tesis. Universitas Hasanuddin Makkasar.

Indrajit, R. E., \& R. Djokropranoto. (2006). Manajemen Perguruan Tinggi Modern. Yogyakarta: CV Andi Offset.

Irawan, P. (1994). Teori Belajar, Motivasi dan Keterampilan Mengejar. Jakar-ta: Pusat Antar Universitas Dirjen Dikti Depdikbud.

Johnson, R. A., \& Dean, W. W. (2003). Wichern Applied Multivariate Statis-tical Analysis. America, New Jersey: Prentice Hall, Inc., Englewood Cliffs.
Kim, J. O.\& Charles, W. M. (1978). Introduction to Faktors Analysis. California: Sage Publication. Ltd.

Koehler, Jerry W., Karl W.E. Anatol., \& Ronald L. Appelbaum. Organizatio-nal Communication. New York: Holt, Ronehart and Winston.

Leavitt, H. J. (1997). Managerial Psy-chology, $4^{\text {th }}$ Edition. Terjemahan oleh Muslichah Zarkasi. Jakarta: Erlang-ga.

Luthans, F. (1995). Organizatinal Behaviour. New York: McGraw Hill.

Maheswari, R., Nisha, R., \& Suraksha, B. (2011). Practicing Instruc-tional Skills Througgh Michro Teaching, (Online), (http://www.scribd. com/ doc/47948472/Practic-ingInstructi-onal-Skills-ThroughMicro-Teach-ing, diakses 20 Febru-ari.

Mahfud, M. M.D. (2009). Kering, Perguruan Tinggi Tanpa Budaya Akademik, (Online), (http://fit.uii.ac.id, di-akses 16 Oktober 2009.

McGarvey, Brian., \& Swallow Derek. (1986). Microteaching in Teacher Educa-tion and Training. London: Croom Helm.

Muhammad, F., Djaali. (2003). Metodo-logi Penelitian Sosial. Jakarta: PTIK Press dan CV Restu Agung.

Pace, R. W., \& Don, F. F. (2005). Komunikasi Organisasi Strategi Meningkatkan Kinerja Perusahaan. Terjemahan oleh Deddy Mulyana. Bandung: PT Remaja Rosdakarya. 
Jurnal Parameter Volume 29 No. 2

DOI : doi.org/10.21009/parameter.292.05

P-ISSN : 0216-26IX

Romdaniyah, S. W. (2009). Analisis Kebijakan Sekolah Bertaraf Interna-sional (SBI), (Online), (http://blogspot.com/2009/06/analisiskebijakan -se-kolah-bertaraf.html, diakses 22 Juni 2009.

Rosyada, D. (2007). Paradigma Pendidikan Demokratis: $\quad$ Sebiah Model Pelibat-an Masyarakat dalam Penyelengga-raan Pendidikan. Jakarta: Prenada Media.

Santoso, S. (2002). Buku Latihan SPSS Statistik Multivariat. Jakarta: PT Elex Media Komputindo Kelompok Gramdeia.

Schartz, P., \& Webb, G. (1990). Case Studies on Teaching in Higher Education. London: Pidden.

Schneider, M. (2011). Publik School Facilities and Teaching: Washington DC and Chicago, (Online), (http:// www.eric.ed.gov/ERICWebPortal/ search/simpleSearch.jsp;jsessionid $=$

ZdluYrZ010dW9WFR3YYYeg_.e ricsrv005?_pageLabel= ERICSearch-Result\&newSearch = true\&ERICE-xtSearch_Descriptor $=$ "Academic +Achievement, diakses 21 Februari 2011.

Semiawan, C. R. (2007). Catatan Kecil tentang Penelitian dan Pengembangan Ilmu Pengetahuan. Jakarta: Kencana Prenoda Media Group.

(1997). Perspektif Pendidikan Anak Berbakat. Jakarta: Grasindo.

Sharma, Subhas. (1996). Applied Multivariate Technique. Canada: Jhon Wiley \& Sons, Inc..
Soegito, E., \&Yuliani, N. (2003). Kemampuan Dasar Mengajar: Modul 1-12. Ja-karta: Universitas Terbuka.

Steers, R. M., \& Lymon, W. P. (1985). Efektivitas Organisasi (Kai-dah Pe-rilaku). Terjemahan oleh Magdalena Jamin. Jakarta: Erlangga.

Sudjana, N. (2004). Penilaian Hasil Proses BelajarMengajar. Bandung: Rema-ja Rosdakarya.

Supartini. (2008). Hubungan Motivasi Belajar dengan Hasil Belajar Siswa di SMK Al-Hidayah I, Jakarta Selatan. Ja-karta: STKIP Purnama.

Surapranata, S. (2004). Analisis Validitas, Re-liabilita, dan InterpretasiHasil Tes Implementasi Kurikulum 2004. Ban-dung: PT Remaja Rosdakarya.

Surya, M. (1997). Psikologi Pembelajaran dan Pengajaran. Ban-dung: PBB IKIP Bandung.

Tenenhaus, M. (2011). Structural Equation Modelling for Small Samples, (Online), (http://www.dec.edu/var/ fre/ storage/original/application/738faf c0860e8ffc1c8f7092a130cd35.pdf . dia-kses 13 Februari 2011.

Tilaar, Anetha. LF. (2009). "Kinerja Guru da-lam Pembelajaran Matematika”. Tesis. Universitas Negeri Jakarta.

Usman, M. U. (2010). Menjadi Guru Profesi-onal. Bandung: PT Remaja Rosda-karya.

Wijaya, T. (2009). Analisis Struktural Equation Model dengan Menggunakan 
Jurnal Parameter Volume 29 No. 2

DOI : doi.org/10.21009/parameter.292.05

P-ISSN : 0216-26IX

Amos. Yogyakarta: Universitas Atmajaya.

Wijayanto, S. H. (2008). Structural Equation Modelling dengan Liserel 8.8: Kon-sep dan Tutorial. Yogya-karta: Gra-ha Ilmu.

dalam Pendidikan, (Online), (http:// mahalaniraya.Wordpress.com/2008/

03/01/pendekatan-total-qualityma-nagement-tqm-dalam-

pendidikan, diakses 29 Juni 2009.

Zakaria, T. R. (2006). Ujian Nasional. Pusat Penilaian Pendidikan Balit-bang Depdiknas.

Zakarsih, P. K., \& M. Mahlani. (2009). Pendekatan Total quality Management 